\title{
Surface growth stress and wood properties of 8-year-old planted Big-leaf mahogany (Swietenia macrophylla King) from different landrace provenances and trial sites in the Philippines
}

\author{
Dennis M. Gilbero ${ }^{1,2}$, Willie P. Abasolo ${ }^{3}$, Miyuki Matsuo-Ueda ${ }^{1}$ and Hiroyuki Yamamoto ${ }^{1 *}$ (]
}

\begin{abstract}
The scarcity of timber to supply the wood-based industries is one of the prevailing problems worldwide. Tree plantations are the remaining solutions to subdue the shortage of raw materials, at the same time sequester atmospheric $\mathrm{CO}_{2}$ in its biomass to reduce global warming. Planting Big-leaf mahogany (Swietenia macrophylla King) contributes valuable economic inputs to small tree farmers in the Philippines. However, the occurrence of lumber defects during processing due to growth stresses reduces the potential value of timber. This study aimed to examine the differences of surface growth stresses and wood properties of an 8-year-old BL mahogany from six landrace provenances in two progeny trial sites, Butuan and Cagayan de Oro in the Philippines. The longitudinal released strains of the surface growth stress (SRS) were not significantly different among six landrace provenances and between two trial sites. The SRS were not significantly related to diameter at breast height $(\mathrm{DBH})$ in both trial sites. The high level of negative SRS was observed in some tested trees with small diameter in both trial sites, which was attributed to the tension wood formation in an irregular-shaped stem. The xylem density (XD), average microfibril angle in the secondary cell wall (MFA), vessel element length (VL) and vessel element width (VW) had no significant differences among six landrace provenances. In terms of trial sites, Butuan trial site gave high lateral growth $\mathrm{DBH}$, high $\mathrm{XD}$, longer fiber length (FL) with a narrow fiber width (FW) and smaller MFA as compared to the Cagayan de Oro trial site. It was observed that an 8-year-old BL mahogany plantation with small-diameter trees exhibited high SRS, low XD, small FL, wide FW and large MFA, which are passively considered as properties of juvenile wood.
\end{abstract}

Keywords: Tropical wood, Growth stress, Wood properties, Field trial, Provenances, Landrace

\section{Introduction}

The Big-leaf (BL) mahogany (Swietenia macrophylla King) is one of the world's most high-valued timber species. For many decades, some countries and/or some private bodies have invested in plantations in order to ensure a sustained production of high-value timber [1,2]. Such cases exist in Asia (Indonesia, Philippines, Sri Lanka

\footnotetext{
*Correspondence: hiro@agr.nagoya-u.ac.jp

${ }^{1}$ Laboratory of Wood Physics, Graduate School of Bio-agricultural

Sciences, Nagoya University, Furo-Cho, Chikusa, Nagoya 464-8601, Japan

Full list of author information is available at the end of the article
}

and Fiji), where the species find good growing conditions [3] as well as, to a lesser extent, in some countries of Central America (Costa Rica) and South America (Brazil, Peru, Bolivia). In 2011 international market, the average price $\$ / \mathrm{m}^{3}$ of BL mahogany sawnwood from Brazil and Guatemala was $\$ 1195 / \mathrm{m}^{3}$ and $\$ 1884 / \mathrm{m}^{3}$, respectively [4].

BL mahogany grows naturally in Belize, Bolivia, Brazil, Colombia, Costa Rica, Ecuador, El Salvador, Guatemala, Honduras, Mexico, Nicaragua, Panama, Peru and Venezuela. However, it is nearly extinct in Ecuador, Colombia, Panama and Costa Rica; close to commercial extinction 
in Bolivia; declining in Mexico, Belize, and Brazil; and in severe decline in Guatemala, Peru, Nicaragua and Honduras $[2,5]$.

The largest plantations of BL mahogany have been reported in South and Southeast Asia and the Pacific regions. BL mahogany has since become a promising tree species for industrial plantations as well as for reforestation and afforestation in Indonesia. BL mahogany is suitable for large-scale timber production plantations because of its excellent timber quality. Generally, the wood can be used for construction materials, plywood (veneer), high-grade furniture and cabinet making. It is also suitable for paneling, framing, flooring, automobile bodies, interior trim of boats, radio and phonograph cabinets, bodies of musical instruments, moldings and other ornaments [6]. However, some wood properties [xylem density (XD), tangential and radial shrinkage, modulus of elasticity (MOE) and modulus of rupture (MOR)] of BL mahogany differ between natural forest and plantation forest [7]; these findings may influence the specific wood utilization of planted BL mahogany.

In the Philippines, BL mahogany is one of the industrial tree plantation species. It was introduced from unknown origins in 1907 as park trees in Manila [8]. In 1913, the forestry school at University of the Philippines Los Baños (UPLB) received 1012 seeds of BL mahogany from an unknown number of parent trees from the Royal Botanic Gardens at Sibpur, Calcutta, India. Since then, there were no other documented reports on mahogany importation into the country until the 1960 s when tree planters in northeastern Mindanao imported an unspecified quantity of seeds directly from an unknown source in Central America [9]. The landrace of BL mahogany in the Philippines has been developed by generations in different provenances.

The increasing deforestation in the country is mainly due to lack of timber supply to augment the existing needs of the growing population. The development of tree plantation is the most efficient way to supply alternative resources while recovering the degraded natural forest. This is also effective in reducing atmospheric $\mathrm{CO}_{2}$ and mitigating climate change. Recently, BL mahogany tree plantation is one of the major sources of lumber and considered as high-value lumber in the local market in the Philippines. One of the prevailing problems in the locally produced lumber is its distorted form after milling and so forth, which in cracks at the edge of the logs decreases the product market value. Only few researchers have investigated that distortion in the lumber form could be attributed to species-specific growth stress inside a $\log$ which is generated during the tree growth [10]. The presence of growth stress in tree stems often causes problems when using processing the logs into timber products. Examples are radial cracks at the edge of cut logs, crooked sawn lumber and so forth [11].

Several studies suggest that the distinctive anatomical characteristics and chemical composition of tension wood directly cause the changes in physical and mechanical properties of wood. This leads to technological problems, such as distortion of solid wood during sawing due to the release of high longitudinal growth stresses, especially in plantation resources [12-16], defects during drying due to its high longitudinal shrinkage [17-21] and severe woolly surface during sawing and rotary cutting [21] due to gelatinous fiber (G-fiber), as well as the bad quality of paper made of G-fibers [22].

However, there are very limited data on the growth stresses and wood qualities as well as the possibility of tension wood formation of planted BL mahogany in the Philippines. Thus, this study aims to examine the differences of surface growth stresses and wood properties of 8-year-old planted BL mahogany from six landrace provenances and two trial sites and also describes the occurrence of tension wood formation in trees. The information generated in this study is very essential for the plantation management of BL mahogany in the Philippines to enhance its uses and productivity.

\section{Materials and methods}

\section{Study area and sample trial sites}

Experimental samples were randomly selected from two established field trial sites of BL mahogany (Swietenia macrophylla King) located in Butuan city and Cagayan de Oro city representing contrasting growing conditions within the target plantation region in northern Mindanao, Philippines (Fig. 1, Table 1).

The field trials were established in September of 2009 by Department of Environment and Natural Resources (DENR Philippines) with support from Commonwealth Scientific and Industrial Research Organization (CSIRO Australia) and Australian government (AusAID Public Sector Linkages Program) [9]. Seeds consist of six landrace provenances in Philippines: Makiling (Laguna), Minglanilla (Cebu), Maasin (Leyte) and Tacloban (Leyte), Bislig (Surigao del Sur) and Lianga (Surigao del Sur) as shown in Fig. 1.

\section{Plant material}

In each trial site, three tested tree samples were randomly selected in each of the six landrace provenances. A total of 36 tested trees in two trial sites were used in the study. Table 2 summarizes the growth data (diameter and height) of the tested trees collected prior to the measurement of various material parameters. 


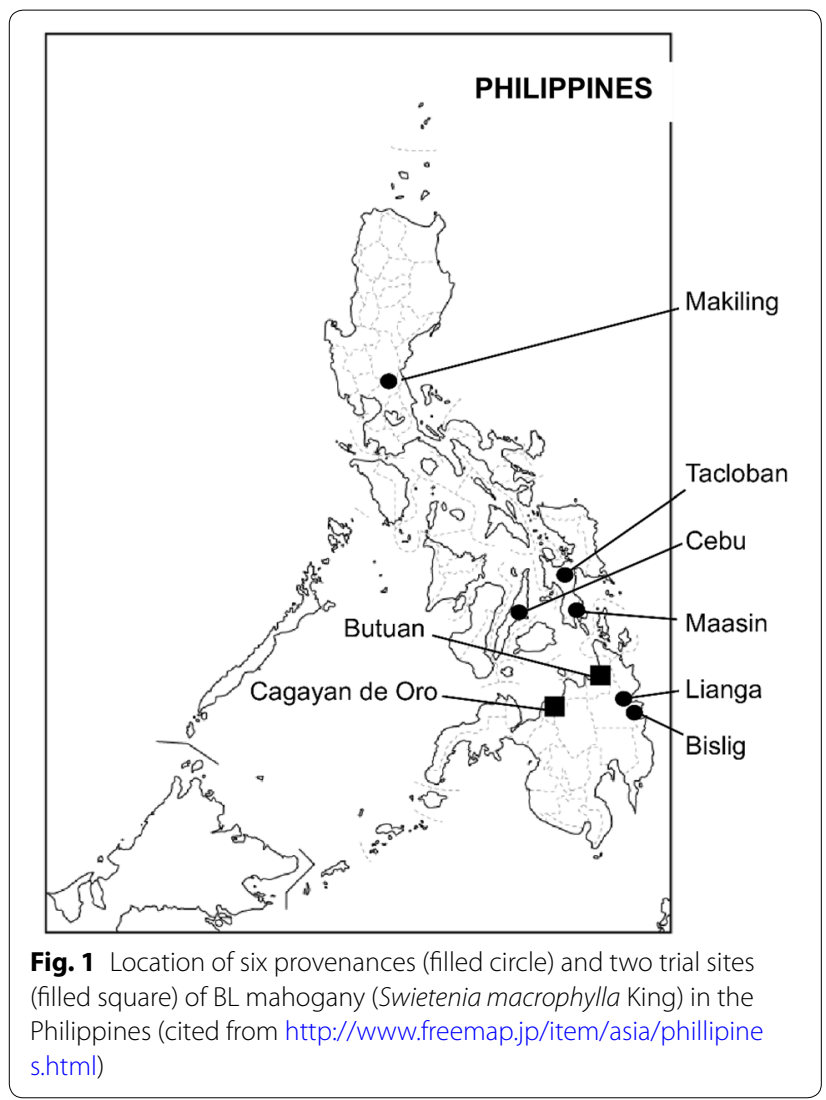

\section{Lateral growth rate-diameter at breast height (DBH)}

The lateral growth rate at diameter at breast height was measured using 1460 planted trees in each trial. These planted trees were composed of 73 individual families of BL mahogany collected from six provenances in the Philippines. In every individual family, five test trees were used which is replicated four times in every trial site.

\section{Longitudinal released strain of surface growth stresses (SRS)}

Growth data (diameter and height) were collected prior to the measurement of various material parameters measured at four cardinal points at the breast height of every tree. Then, the longitudinal released strain of the surface growth stresses (SRS) was measured. A rectangular specimen was then collected at the point where the SRS was measured and used to measure xylem density (XD), fiber length (FL), fiber width (FW), vessel element length (VL), vessel element width (VW) and the average microfibril angle in the cell wall (MFA). The values measured at the four cardinal points were averaged for each test tree [24]. In addition to the above-tested trees, two trees with inclined stem were selected in Butuan trial site.

For each standing tree, measurement was conducted at four cardinal points (North, South, East and West) at $\mathrm{DBH}$ (1.3 $\mathrm{m}$ from the ground). A strain gauge (electric-wire strain gauge, $10 \mathrm{~mm}$ length, KFG-10-120-C111L3M3R, Kyowa Co., Tokyo, Japan) was glued to the exposed secondary xylem surface along the longitudinal direction and was connected to a strain meter (UCAM1A, Kyowa Co., Tokyo, Japan). After measuring the initial strain on the tree sample, the surface stress was released using a handsaw, and the strain was then recorded. The amount of SRS was calculated by subtracting the initial measurement from the second reading [24-27].

\section{Xylem density (XD)}

Wood samples $(1 \mathrm{~cm} \times 1 \mathrm{~cm} \times 1 \mathrm{~cm})$ were prepared from the rectangular specimen taken from the points where the SRS was measured. These samples were seasoned at room temperature inside desiccators containing a saturated aqueous solution of $\mathrm{NaCl}$ for 1 week until equilibrium for "air-dried density" measurement denoted as XD. The density was determined using the mercury displacement method [15, 28].

\section{Fiber length (FL), fiber width (FW), vessel element length (VL) and vessel element width (VW)}

After the measurement of XD, part of each cubic specimen was treated in a compound liquid of water, potassium chlorate and $60 \%$ nitric acid [29], followed by $10 \%$ $\mathrm{NaOH}$ (aq) treatment and then defiberized [30] and dispersed in an aqueous suspension. A drop of defiberized wood suspension was placed on a glass slide and then covered with a cover slip. Using a digital microscope (Olympus BX60), digital images of all 90 fiber samples

Table 1 Location and description of sampling sites $[9,23]$

\begin{tabular}{|c|c|c|c|c|c|c|c|c|}
\hline \multirow[t]{2}{*}{ Trial site } & \multicolumn{2}{|l|}{ Location } & \multirow[t]{2}{*}{ Altitude (m) } & \multirow{2}{*}{$\begin{array}{l}\text { Annual } \\
\text { rainfall }(\mathrm{mm})\end{array}$} & \multicolumn{4}{|l|}{ Soil } \\
\hline & Latitude & Longitude & & & $\mathrm{pH}$ & $\begin{array}{l}\text { Organic } \\
\text { matter (\%) }\end{array}$ & $\begin{array}{l}\text { Phosphorus } \\
\text { (ppm) }\end{array}$ & $\begin{array}{l}\text { Potassium } \\
\text { (ppm) }\end{array}$ \\
\hline Butuan & $8^{\circ} 56^{\prime} N$ & $125^{\circ} 35^{\prime} \mathrm{E}$ & $13-15$ & 2057 & 6.8 & 1.2 & 4.5 & 144 \\
\hline Cagayan de Oro & $8^{\circ} 23^{\prime} \mathrm{N}$ & $124^{\circ} 42^{\prime} \mathrm{E}$ & $413-415$ & 1703 & 5.8 & 4.5 & 1.3 & 48 \\
\hline
\end{tabular}


Table 2 Summary of growth data of sampled trees at each of the trial sites and landrace provenances: averages and standard deviations of diameter at breast height $(\mathrm{DBH})$ and tree height $(\mathrm{Ht})$

\begin{tabular}{|c|c|c|c|c|c|}
\hline Trial sites & Provenances & $n$ & & Average DBH (SD) cm & Average $\mathrm{Ht}$ (SD) $\mathrm{m}$ \\
\hline \multirow[t]{7}{*}{ Butuan } & Bislig & 3 & & $33.00(9.61)$ & $21.00(4.58)$ \\
\hline & Cebu & 3 & & $36.60(10.62)$ & $21.00(2.65)$ \\
\hline & Lianga & 3 & & $37.70(7.91)$ & $22.00(2.52)$ \\
\hline & Maasin & 3 & & $22.00(2.60)$ & $18.00(0.58)$ \\
\hline & Makiling & 3 & & $30.00(7.65)$ & $20.00(2.00)$ \\
\hline & Tacloban & 3 & & $24.00(4.69)$ & $19.00(1.53)$ \\
\hline & Total & 18 & Average & $30.55(7.18)$ & $20.17(2.31)$ \\
\hline \multirow[t]{7}{*}{ Cagayan de Oro } & Bislig & 3 & & $22.40(8.13)$ & $9.00(2.00)$ \\
\hline & Cebu & 3 & & $22.30(8.25)$ & $10.00(2.08)$ \\
\hline & Lianga & 3 & & $26.30(10.65)$ & $9.00(0.58)$ \\
\hline & Maasin & 3 & & $21.00(6.47)$ & $12.00(3.61)$ \\
\hline & Makiling & 3 & & $23.50(8.59)$ & $14.00(4.73)$ \\
\hline & Tacloban & 3 & & $22.00(7.54)$ & $11.00(3.06)$ \\
\hline & Total & 18 & Average & $22.92(8.27)$ & $10.83(2.67)$ \\
\hline
\end{tabular}

were randomly selected and captured. All vessel elements were also captured. The captured images were processed using image processor software (Image J ver.1.51K) to measure FL, FW, VL and VW.

\section{Average microfibril angle in the secondary cell wall (MFA)} From another part of the rectangular wood specimen for $\mathrm{XD}$ measurement, a small specimen $[0.1(\mathrm{R}) \times 1(\mathrm{~T}) \times 1(\mathrm{~L})$ $\mathrm{cm}$ ] was derived for MFA determination using the X-ray diffractometry (Ultima IV, Rigaku Corporation) following the method of Cave [24, 31-33]. The data generated from the X-ray diffractometry were the average MFA of the secondary cell wall $\left(S_{2}\right.$ and $\left.G\right)$.

\section{Statistical analysis}

Three trees were selected from each of the six landrace provenances per trial site by the complete random design. A total of 36 test trees were tested in two trial sites. In every tested tree, there were four measuring points (cardinal directions) assigned for the measurement of SRS, $\mathrm{XD}, \mathrm{FL}, \mathrm{FW}, \mathrm{VL}, \mathrm{VW}$ and MFA. A total of 144 sampling points were derived from 36 randomly selected test trees from six different landrace provenances of two trial sites. Simple linear regression models were used to test the correlation between the lateral growth rate and wood properties: SRS, XD, FL, FW, VL, VW and MFA. The comparison in wood properties: SRS, XD, FL, FW, VL, VW and MFA, among provenances and between trial sites was tested using a two-way analysis of variance (ANOVA) and Scheffe's method for multiple-comparison tests using SPSS v20 software.

\section{Results and discussion}

Lateral growth rate-diameter at breast height (DBH)

Comparing DBH of all planted trees among six landrace provenances and between two trial sites (Fig. 2), the result showed that DBH among six landrace provenances has no significant difference (Table 3), while the difference between two trial sites was highly significant. The average DBH of two trials sites was $23.25 \mathrm{~cm}$ and $14.17 \mathrm{~cm}$ for Butuan and Cagayan de Oro, respectively. Regardless of provenances, Butuan trial site produced bigger-diameter trees than the Cagayan de Oro trial site.

\section{Longitudinal released strain of surface growth stresses (SRS)}

SRS in each tested tree is shown in Fig. 3. Six landrace provenances (Makiling, Cebu, Maasin, Tacloban, Lianga and Bislig) in two trial sites (Butuan and Cagayan de Oro) gave similar SRS. The differences in the average SRS among six landrace provenances and between trial sites were analyzed using a two-way ANOVA and Scheffe's post hoc multiple-comparison method. Results showed no significant differences among landrace provenances and between trial sites, as well as no significant interaction between provenance and trial site (Tables 3 and 4). It has been reported that SRS has been found similar to the studies on tropical species, e.g., Tectona grandis [34] and Eucalyptus grandis in different latitudes [16, 35], regardless of the lateral growth.

The relationship between DBH and averaged SRS is shown in Fig. 4 and Table 5. It reveals no significant correlations were observed in both trial sites. 


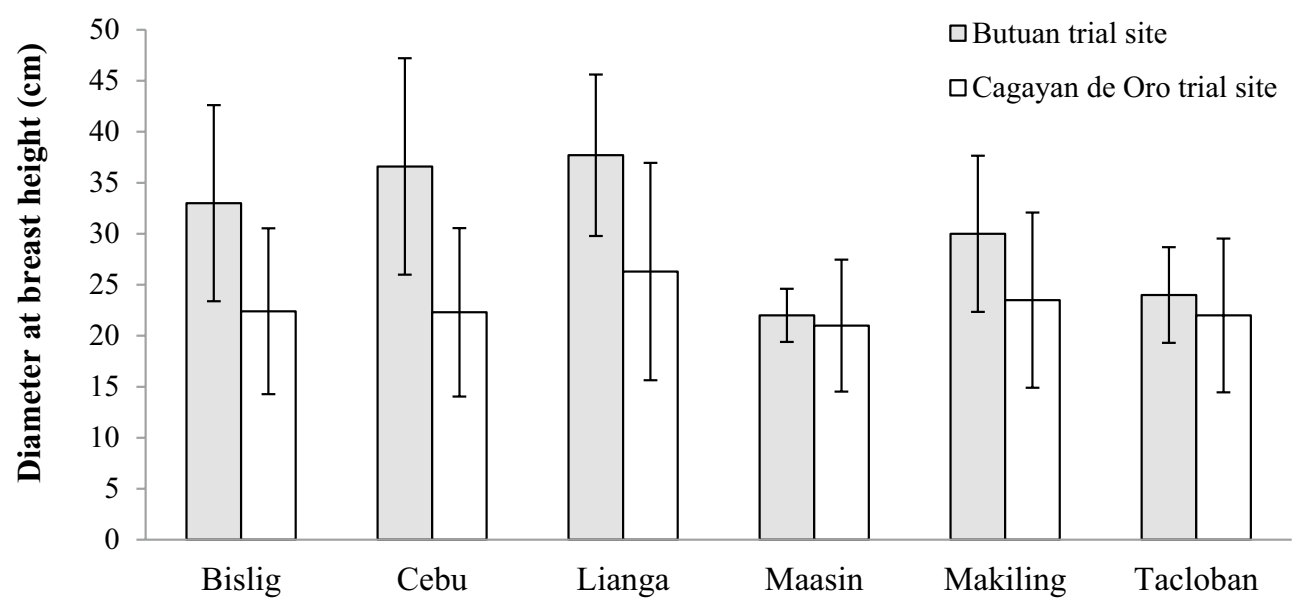

Fig. 2 The distribution of averaged DBH of all planted trees of BL mahogany from six landrace provenances in two trial sites: Butuan trial Site and Cagayan de Oro trial site. Number of samples $=2920$ trees (1460 trees in every trial site); bar stands for \pm 1 standard deviation

Table 3 Two-way analysis of variance (ANOVA) for the effects of six landrace provenances and two trial sites on lateral growth, surface-released strain and wood properties averaged in each tested tree

\begin{tabular}{|c|c|c|c|c|c|}
\hline Parameters & Source of variance & $d f$ & SS & MS & Sig. ( $p$-value) \\
\hline \multirow[t]{3}{*}{ Diameter at breast height (cm) } & Trial site & 1 & 2966.62 & 63.15 & 0.000 \\
\hline & Provenance & 5 & 413.62 & 82.72 & 0.125 \\
\hline & Provenance $\times$ trial site & 5 & 425.37 & 85.07 & 0.115 \\
\hline \multirow[t]{3}{*}{ Surface release strain (\%) } & Trial site & 1 & 0.00 & 0.00 & 0.622 \\
\hline & Provenance & 5 & 0.00 & 0.00 & 0.436 \\
\hline & Provenance $\times$ trial site & 5 & 0.00 & 0.00 & 0.715 \\
\hline \multirow[t]{3}{*}{ Xylem density $\left(\mathrm{g} / \mathrm{cm}^{3}\right)$} & Trial site & 1 & 0.15 & 0.15 & 0.000 \\
\hline & Provenance & 5 & 0.03 & 0.01 & 0.182 \\
\hline & Provenance $\times$ trial site & 5 & 0.08 & 0.02 & 0.004 \\
\hline \multirow[t]{3}{*}{ Fiber length (mm) } & Trial site & 1 & 0.31 & 0.31 & 0.000 \\
\hline & Provenance & 5 & 0.24 & 0.05 & 0.000 \\
\hline & Provenance $\times$ trial site & 5 & 0.09 & 0.02 & 0.043 \\
\hline \multirow[t]{3}{*}{ Fiber width (mm) } & Trial site & 1 & 0.00 & 0.00 & 0.000 \\
\hline & Provenance & 5 & 0.00 & 0.00 & 0.000 \\
\hline & Provenance $\times$ trial site & 5 & 0.00 & 0.00 & 0.000 \\
\hline \multirow[t]{3}{*}{ Vessel element length (mm) } & Trial site & 1 & 0.00 & 0.00 & 0.899 \\
\hline & Provenance & 5 & 0.04 & 0.01 & 0.073 \\
\hline & Provenance $\times$ trial site & 5 & 0.01 & 0.00 & 0.736 \\
\hline \multirow[t]{3}{*}{ Vessel element width (mm) } & Trial site & 1 & 0.00 & 0.00 & 0.688 \\
\hline & Provenance & 5 & 0.02 & 0.00 & 0.479 \\
\hline & Provenance $\times$ trial site & 5 & 0.01 & 0.00 & 0.580 \\
\hline \multirow[t]{3}{*}{ Microfiber angle $\left(^{\circ}\right)$} & Trial site & 1 & 589.18 & 589.18 & 0.000 \\
\hline & Provenance & 5 & 260.06 & 52.01 & 0.062 \\
\hline & Provenance $\times$ trial site & 5 & 162.80 & 32.56 & 0.245 \\
\hline
\end{tabular}

\section{Xylem density (XD)}

The differences in the average XD among six landrace provenances and between two trial sites were analyzed using a two-way ANOVA and Scheffe's multiple-comparison (post hoc) method. Result showed no significant differences among six landrace provenances and high significant differences between two 
(a)
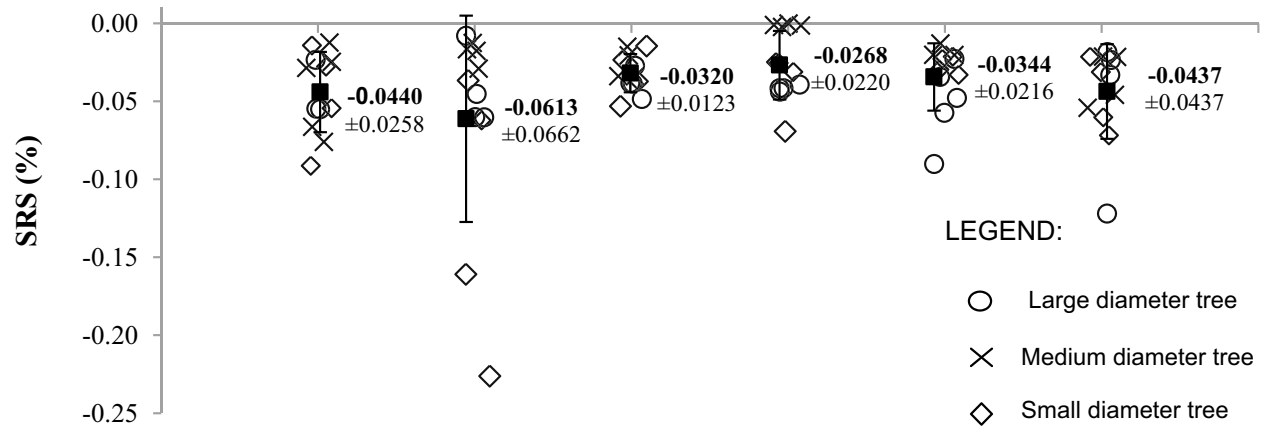

O

LEGEND:

0

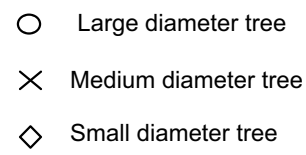

$\diamond \quad$ Small diameter tree

(b)

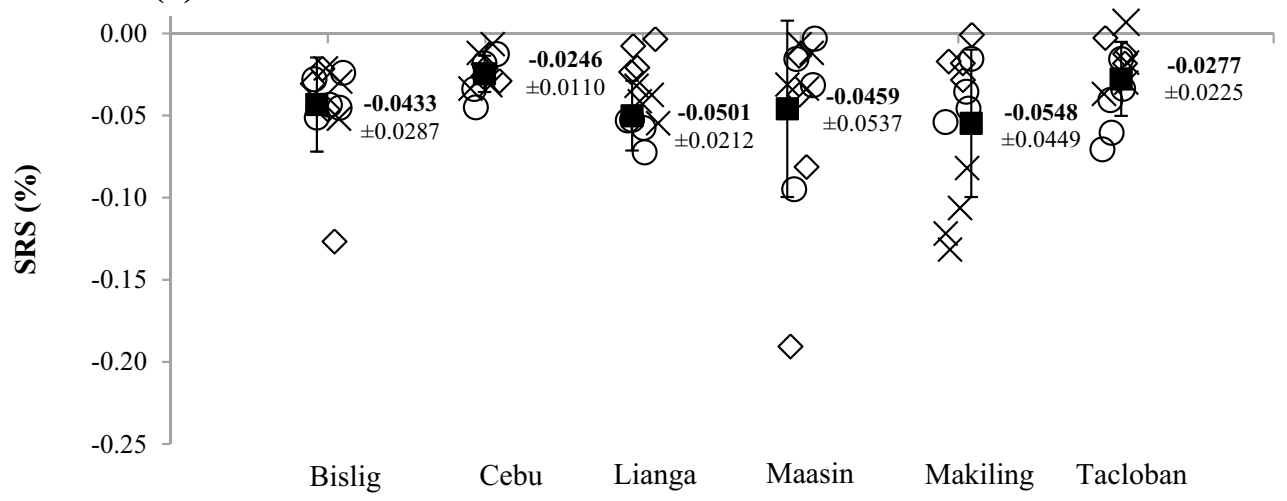

Fig. 3 The longitudinal released strain of surface growth stress (SRS) in tested trees in six landrace provenances at two trial sites a SRS (\%) at Butuan trial site and $\mathbf{b}$ SRS (\%) at Cagayan de Oro trial site. All the values are the averaged (filled square), with \pm 1 standard deviation in each provenance

Table 4 Scheffe's multiple-comparison test for the effect of six landrace provenances on lateral growth and wood properties in tested trees

\begin{tabular}{|c|c|c|c|c|c|c|}
\hline \multirow[t]{2}{*}{ Parameters } & \multicolumn{6}{|l|}{ Provenances } \\
\hline & Bislig & Cebu & Lianga & Maasin & Makiling & Tacloban \\
\hline Diameter at breast height $(\mathrm{cm})$ & $18.07(8.79)^{\mathrm{a}}$ & $19.22(10.12)^{a}$ & $21.93(10.82)^{\mathrm{a}}$ & $16.50(5.09)^{\mathrm{a}}$ & $18.95(7.68)^{\mathrm{a}}$ & $17.60(5.90)^{\mathrm{a}}$ \\
\hline Surface release strain (\%) & $-0.04(0.02)^{\mathrm{a}}$ & $-0.03(0.02)^{\mathrm{a}}$ & $-0.04(0.02)^{\mathrm{a}}$ & $-0.03(0.02)^{\mathrm{a}}$ & $-0.03(0.02)^{\mathrm{a}}$ & $-0.03(0.02)^{\mathrm{a}}$ \\
\hline Xylem density $\left(\mathrm{g} / \mathrm{cm}^{3}\right)$ & $0.58(0.07)^{\mathrm{a}}$ & $0.60(0.09)^{\mathrm{a}}$ & $0.59(0.04)^{\mathrm{a}}$ & $0.61(0.10)^{\mathrm{a}}$ & $0.63(0.08)^{\mathrm{a}}$ & $0.59(0.05)^{\mathrm{a}}$ \\
\hline Fiber length (mm) & $1.08(0.06)^{\mathrm{a}}$ & $1.08(0.12)^{\mathrm{a}}$ & $1.14(0.13)^{\mathrm{ab}}$ & $1.13(0.09)^{\mathrm{ab}}$ & $1.17(0.10)^{b}$ & $1.18(0.08)^{b}$ \\
\hline Fiber width (mm) & $0.03(0.00)^{\mathrm{ab}}$ & $0.02(0.00)^{\mathrm{a}}$ & $0.03(0.00)^{b}$ & $0.03(0.00)^{b}$ & $0.03(0.00)^{b}$ & $0.03(0.00)^{b}$ \\
\hline Vessel element length (mm) & $0.43(0.04)^{\mathrm{a}}$ & $0.39(0.06)^{\mathrm{a}}$ & $0.44(0.06)^{\mathrm{a}}$ & $0.42(0.09)^{\mathrm{a}}$ & $0.42(0.04)^{\mathrm{a}}$ & $0.41(0.04)^{a}$ \\
\hline Vessel element width (mm) & $0.21(0.06)^{\mathrm{a}}$ & $0.19(0.04)^{\mathrm{a}}$ & $0.22(0.05)^{\mathrm{a}}$ & $0.20(0.09)^{\mathrm{a}}$ & $0.21(0.04)^{\mathrm{a}}$ & $0.19(0.04)^{\mathrm{a}}$ \\
\hline Microfiber angle $\left({ }^{\circ}\right)$ & $21.06(3.67)^{\mathrm{a}}$ & $22.42(5.37)^{\mathrm{a}}$ & $20.01(5.11)^{\mathrm{a}}$ & $24.30(4.40)^{\mathrm{a}}$ & $21.08(7.06)^{\mathrm{a}}$ & $22.42(5.84)^{\mathrm{a}}$ \\
\hline
\end{tabular}

Values in parenthesis are standard deviation

Means followed by the same letters $(\mathrm{a}, \mathrm{b})$ in the same row are not significantly different at $p \leq 0.05$ according to Scheffe's method

trial sites, as well as a highly significant interaction between provenance and trial site (Table 3).

The relationship between $\mathrm{DBH}$ and XD is shown in Fig. 5 and Table 5. There were no correlations between
Butuan and Cagayan de Oro trial site. These results were the same as with the findings of Kojima et al. [24] (Gmelina arborea) and Zobel and Jett [36] (Populus tremuloides and Eucalyptus grandis) who found out that a 
(a)

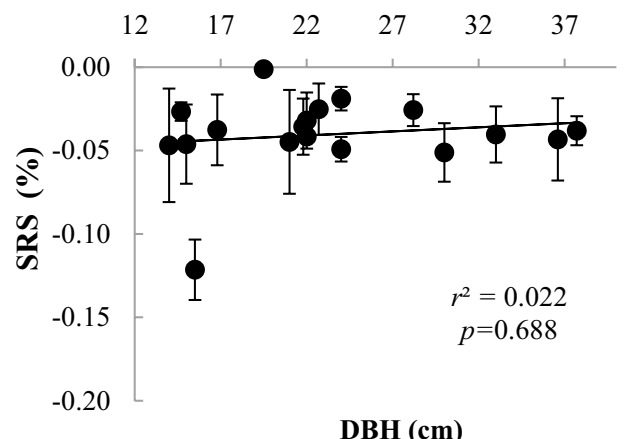

(b)

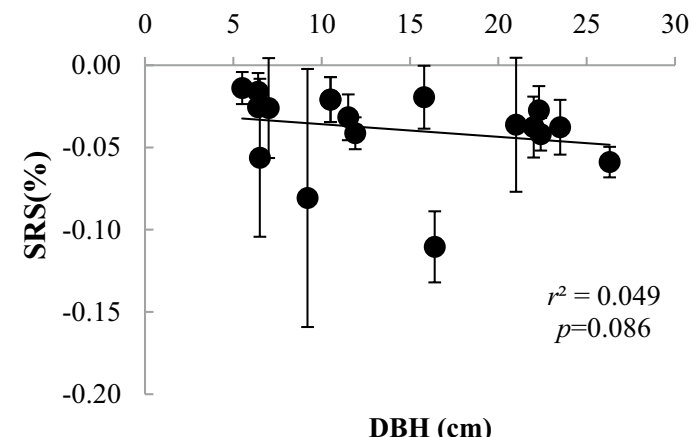

Fig. 4 The relationship between DBH and SRS averaged in each tested tree with \pm 1 standard deviation in two trial sites $\mathbf{a}$ Butuan trial site and $\mathbf{b}$ Cagayan de Oro trial site

Table 5 Correlation matrices of lateral growth and wood properties in tested trees in two trial sites

\begin{tabular}{|c|c|c|c|c|c|c|c|c|c|}
\hline Variables & Trial site & & SRS & MFA & $X D$ & $\mathrm{FL}$ & FW & $\mathrm{VL}$ & vw \\
\hline \multirow[t]{4}{*}{ DBH } & Butuan & Pearson correlation & -0.10 & 0.11 & -0.42 & 0.12 & -0.19 & 0.22 & $0.51^{*}$ \\
\hline & & $N$ & 18 & 18 & 18 & 18 & 18 & 18 & 18 \\
\hline & Cagayan de Oro & Pearson correlation & -0.42 & -0.44 & -0.21 & 0.21 & 0.16 & 0.09 & 0.44 \\
\hline & & $N$ & 18 & 18 & 18 & 18 & 18 & 18 & 18 \\
\hline \multirow[t]{4}{*}{ SRS } & Butuan & Pearson correlation & & -0.02 & $0.39 * *$ & -0.01 & 0.19 & 0.06 & -0.03 \\
\hline & & $N$ & & 67 & 67 & 67 & 66 & 66 & 66 \\
\hline & Cagayan de Oro & Pearson correlation & & $0.38^{* *}$ & 0.00 & 0.03 & -0.06 & 0.20 & -0.16 \\
\hline & & $N$ & & 62 & 65 & 65 & 65 & 65 & 65 \\
\hline \multirow[t]{4}{*}{ MFA } & Butuan & Pearson correlation & & & 0.22 & -0.11 & -0.12 & -0.28 & -0.25 \\
\hline & & $N$ & & & 72 & 71 & 71 & 71 & 71 \\
\hline & Cagayan de Oro & Pearson correlation & & & -0.01 & 0.06 & 0.08 & 0.08 & -0.20 \\
\hline & & $N$ & & & 67 & 67 & 67 & 67 & 67 \\
\hline \multirow[t]{4}{*}{$X D$} & Butuan & Pearson correlation & & & & 0.07 & 0.11 & -0.08 & -0.21 \\
\hline & & $N$ & & & & 71 & 71 & 71 & 71 \\
\hline & Cagayan de Oro & Pearson correlation & & & & -0.09 & -0.05 & -0.13 & -0.04 \\
\hline & & $N$ & & & & 72 & 72 & 72 & 72 \\
\hline \multirow[t]{4}{*}{$\mathrm{FL}$} & Butuan & Pearson correlation & & & & & -0.25 & -0.02 & 0.09 \\
\hline & & $N$ & & & & & 70 & 70 & 70 \\
\hline & Cagayan de Oro & Pearson correlation & & & & & $0.287^{*}$ & $0.53^{* *}$ & -0.04 \\
\hline & & $N$ & & & & & 72 & 72 & 72 \\
\hline \multirow[t]{4}{*}{ FW } & Butuan & Pearson correlation & & & & & & $0.270^{*}$ & $0.35^{* *}$ \\
\hline & & $N$ & & & & & & 71 & 71 \\
\hline & Cagayan de Oro & Pearson correlation & & & & & & 0.15 & 0.16 \\
\hline & & $N$ & & & & & & 72 & 72 \\
\hline \multirow[t]{4}{*}{$V L$} & Butuan & Pearson correlation & & & & & & & 0.14 \\
\hline & & $N$ & & & & & & & 71 \\
\hline & Cagayan de Oro & Pearson correlation & & & & & & & -0.30 \\
\hline & & $N$ & & & & & & & 72 \\
\hline
\end{tabular}

*Correlation is significant at the 0.05 level (2-tailed)

**Correlation is significant at the 0.01 level (2-tailed) 


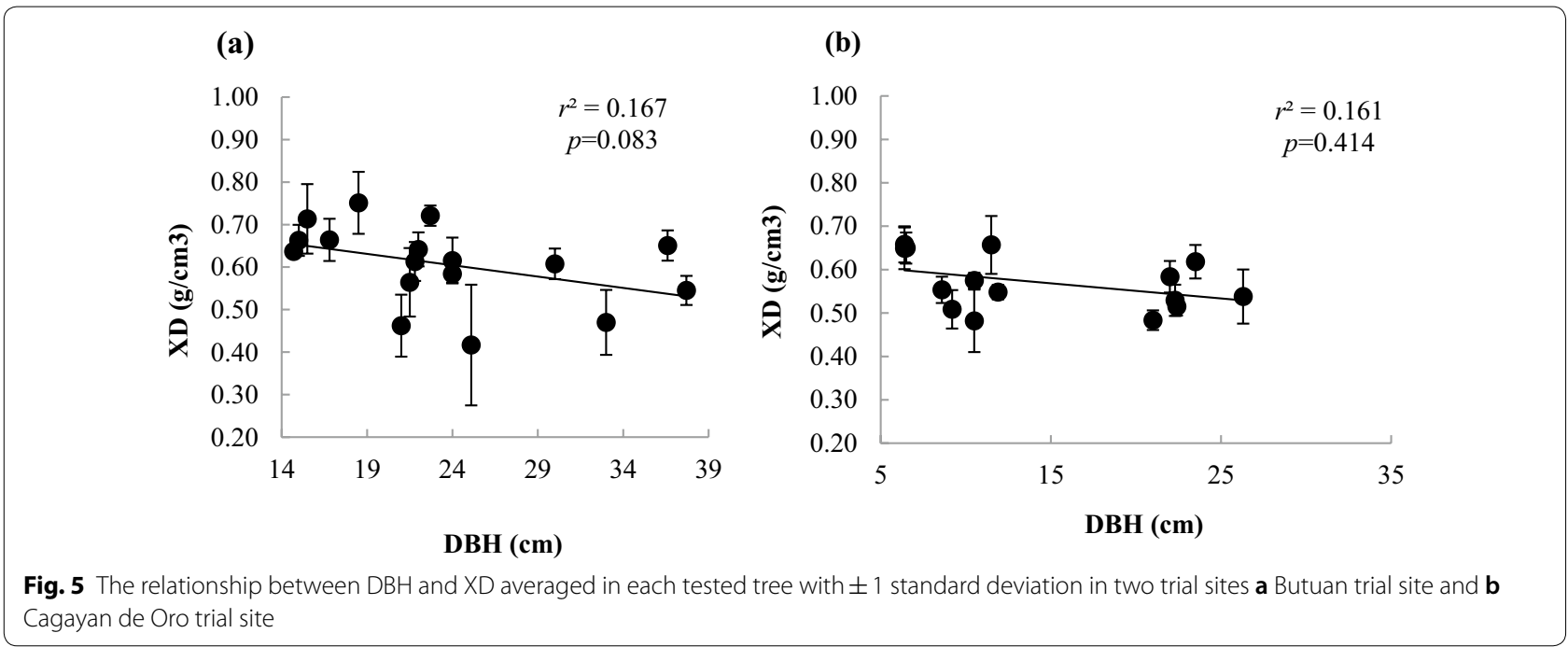

diffuse-porous hardwood species usually show little or no relationship between growth rate and xylem density.

\section{Fiber length (FL), fiber width (FW), vessel element length (VL) and vessel element width (VW)}

Tables 3 and 4 show that FL and FW averaged at each measuring point have significant differences among six landrace provenances and trial sites. Landrace provenances from Makiling and Tacloban give the highest average FL of $1.172 \mathrm{~mm}$ and $1.176 \mathrm{~mm}$, respectively. And highest average FW was in the landrace provenances of Lianga $(0.027 \mathrm{~mm})$, Maasin $(0.027 \mathrm{~mm})$, Makiling $(0.027 \mathrm{~mm})$ and Tacloban $(0.026 \mathrm{~mm})$. High significant differences were found between two trial sites; Butuan trial site has larger FL $(1.175 \mathrm{~mm})$ with thinner FW $(0.023 \mathrm{~mm})$ as compared with Cagayan de Oro trial site which has shorter FL $(1.082 \mathrm{~mm})$ and wider FW $(0.029 \mathrm{~mm})$. The high growth rate condition in Butuan trial site promotes longer, but thinner fiber. This result partly coincides with the findings that higher growth rate in the tropical plantation promotes longer FL [15]. Previous studies also reported that shorter fiber and narrow vessel element are characteristic of juvenile wood $[36,37]$. It is considered that some trees of 8-year-old BL mahogany could still produce juvenile wood. The VL and VW have no significant difference among six landrace provenances and two trial sites.

The FL, FW and VL in Butuan and Cagayan de Oro trial sites were not correlated in terms of DBH (Table 5). However, VW was positively correlated with DBH in Butuan trial site but not in Cagayan de Oro trial site as shown in Fig. 6. The relationship between VL and FL was positive only in Cagayan de Oro trial site which exhibited smaller average DBH as compared with the Butuan trial site (Fig. 7 and Table 5). The VL and VW have no significant interaction between landrace provenances and trial sites, as compared to FW with high significant interaction between landraces provenances and trial sites (Table 3).

It was also considered that the formation of tension wood was related to shorter fiber and vessel element. Some studies have reported that the tension wood contains a lower vessel proportion than normal wood $[18,19$, $38,39]$.

\section{Average microfibril angle in the secondary cell wall (MFA)}

The MFA is considered to have a major role in controlling certain fiber qualities, including fiber stiffness and dimensional stability [40].

The differences of average MFA on each tested tree among six landrace provenances and between two trial sites were also analyzed by a two-way ANOVA and Scheffe's multiple-comparison (post hoc) method. This analysis indicated no significant difference among six landrace provenances and a high significant difference between two trials sites with an average MFA of $19.82^{\circ}$ in Butuan and 24.94 in Cagayan de Oro trial sites (Tables 3 and 4).

The effect of the DBH on MFA averaged in each tree is shown in Fig. 8 and Table 5. DBH has no significant correlation with averaged MFA in both trial sites. Same results were observed in Acacia mangium, A. auriculiformis, hybrid Acacia (Acacia mangium $\times$ A. auriculiformis), Eucalyptus grandis, E. globulus and Falcataria moluccana, indicating that in these cases, acceleration of secondary growth does not affect the MFA at the outermost surface of the xylem [15].

The effects of MFA on SRS showed no correlation in Butuan trial site, but a positive correlation was observed 

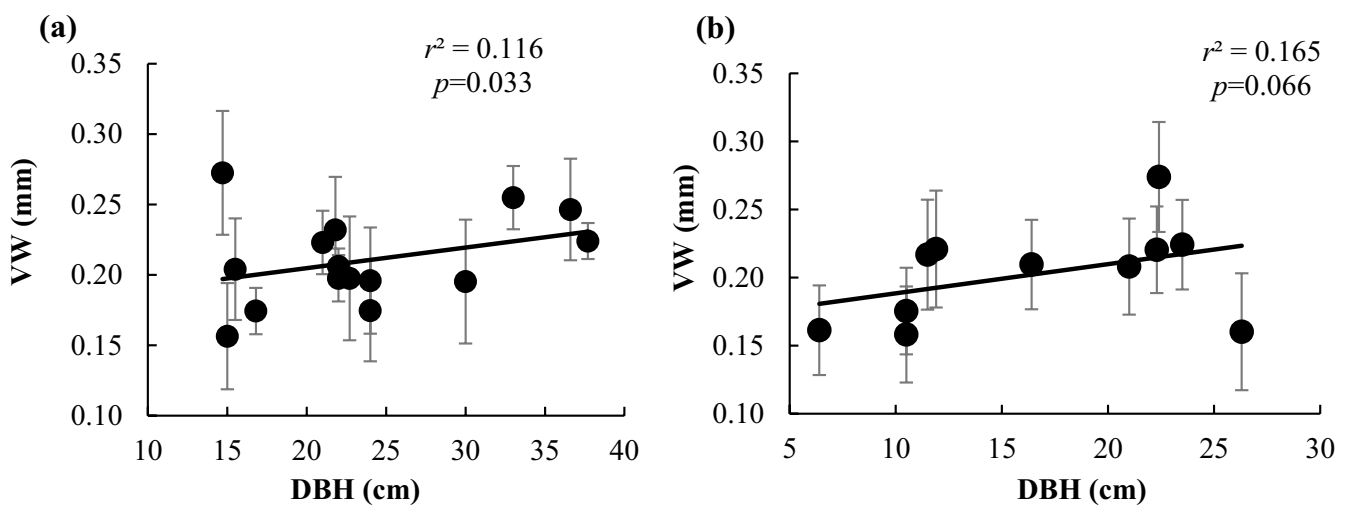

Fig. 6 The relationship between DBH and VW averaged in each tested tree with \pm 1 standard deviation in two trial sites $\mathbf{a}$ Butuan trial site and $\mathbf{b}$ Cagayan de Oro trial site

(a)

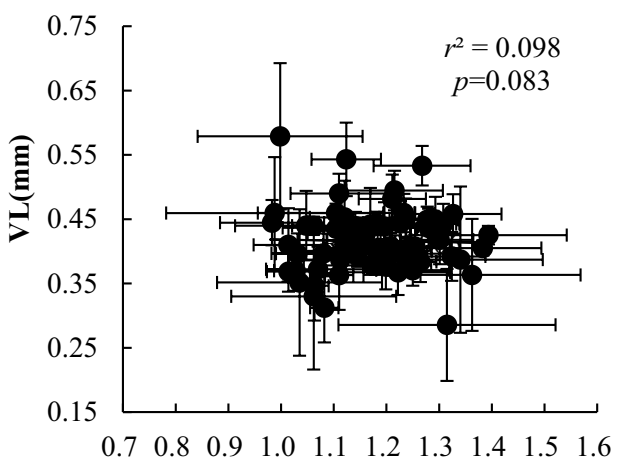

FL (mm) (b)

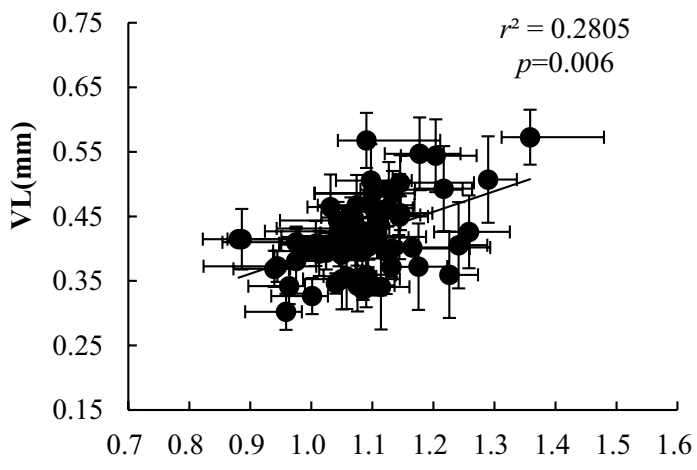

FL (mm)

Fig. 7 The relationship between FL and VL averaged at each measuring point in each tested tree in two trial sites a Butuan trial site and $\mathbf{b}$ Cagayan de Oro trial site. Each bar is \pm 1 standard deviation
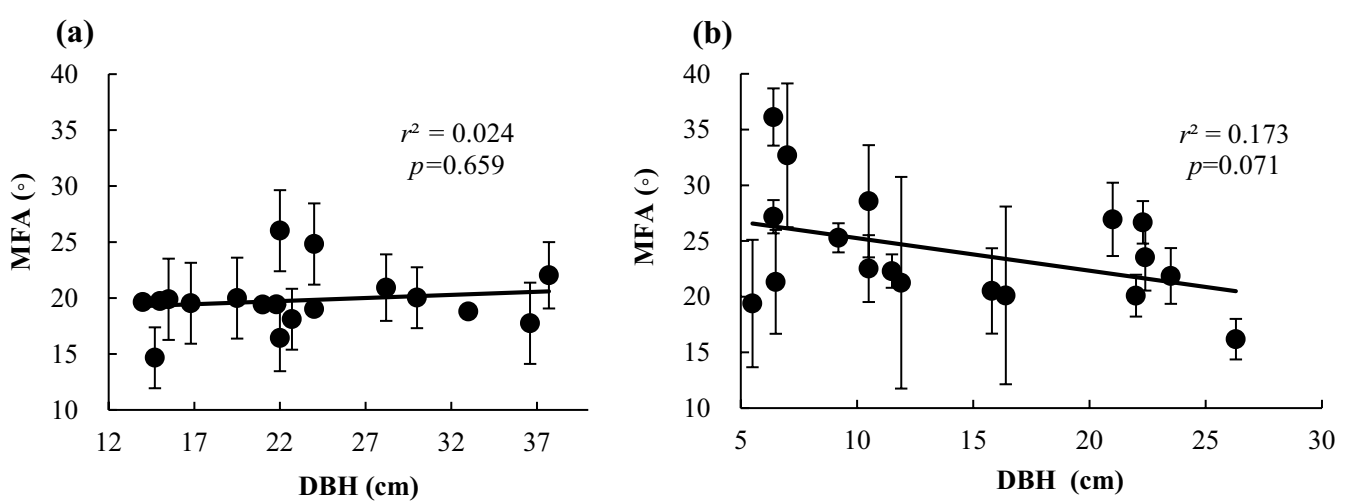

Fig. 8 The relationship between DBH and MFA averaged in each tested tree with \pm 1 standard deviation in two trial sites $\mathbf{a}$ Butuan trial site, $\mathbf{b}$ Cagayan de Oro trial site 
in the Cagayan de Oro trial site (Fig. 9 and Table 5). MFA has no significant interaction between landrace provenances and trial sites (Table 3). It is reported that there might be a causal relationship between both qualities in a small-diameter tree, e.g., formation of the tension wood fiber with a thick gelatinous layer (G-layer) and low MFA in several hardwood species [13, 14, 16]. MFA values smaller than 10 degrees are often correlated with high tensile stress generation in tension wood compared with normal wood [12-14, 41-44]. In tension wood, the tensile growth stress increases with the amount of gelatinous fibers, increasing cellulose content and decreasing MFA [41-43, 45, 46]. Same findings were confirmed also in 8-year-old BL mahogany based on a separate experiment using two inclined mature stems as shown in Figs. 10 and 11. In tension wood, the longitudinal growth stress possesses a very large tensile value. The presence of growth stress in tree stems often causes problems when using logs as raw material for timber products. Examples are radial cracks at the edge of cut logs, crooked sawn lumber, and so forth [10]. Processing of BL mahogany timber with tension wood should be avoided until the desired practical solution will be applied to solve this problem.

\section{Conclusion}

The results indicate that the SRS was invariable regardless of landrace provenances and trial sites. The XD, VL, VW and MFA have no significant differences among six landrace provenances. And FL and FW have high significant differences among six landrace provenances. It was found out in this study that Butuan trial site has a high lateral growth $\mathrm{DBH}$, high XD, longer FL with a narrow FW and a smaller MFA compared with

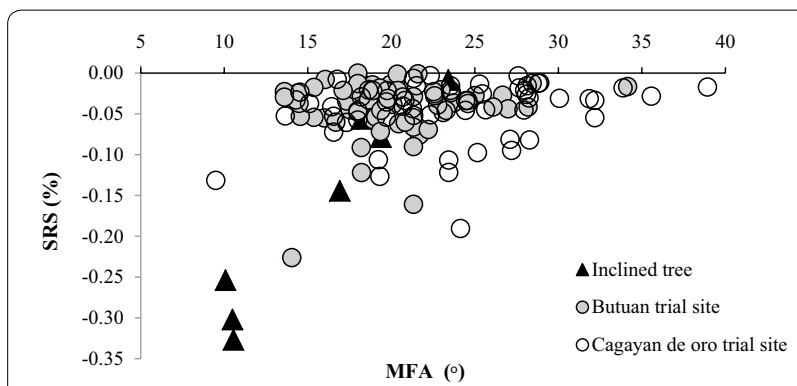

Fig. 10 The relationship between MFA and SRS at each measurement point in each tested tree in two trial sites and in two tested trees containing tension wood on the upper side along the inclined stems

the Cagayan de Oro trial site. However, in terms of VL and VW, no significant differences between two trial sites were observed. In both trial sites, DBH does not affect SRS, MFA, XD, VL, FL and FW. However, VW was positively correlated only in the Butuan trial site.

A small-diameter tree exhibits high SRS, small FL, wide FW and large MFA. A high level of SRS was observed in some tested trees with a small diameter growth, which was attributed to tension wood formation. These suggest that the current cambium age is still producing juvenile wood, especially in a smaller diameter tree. It is recommended to conduct further investigations on the xylem maturation properties of $\mathrm{BL}$ mahogany in relation to diameter growth and cambial ages. In order to avoid leaning trees with tension wood in tree plantation for timber production, it is necessary therefore to avoid planting trees in sloping areas and employ required spacing in silvicultural management.
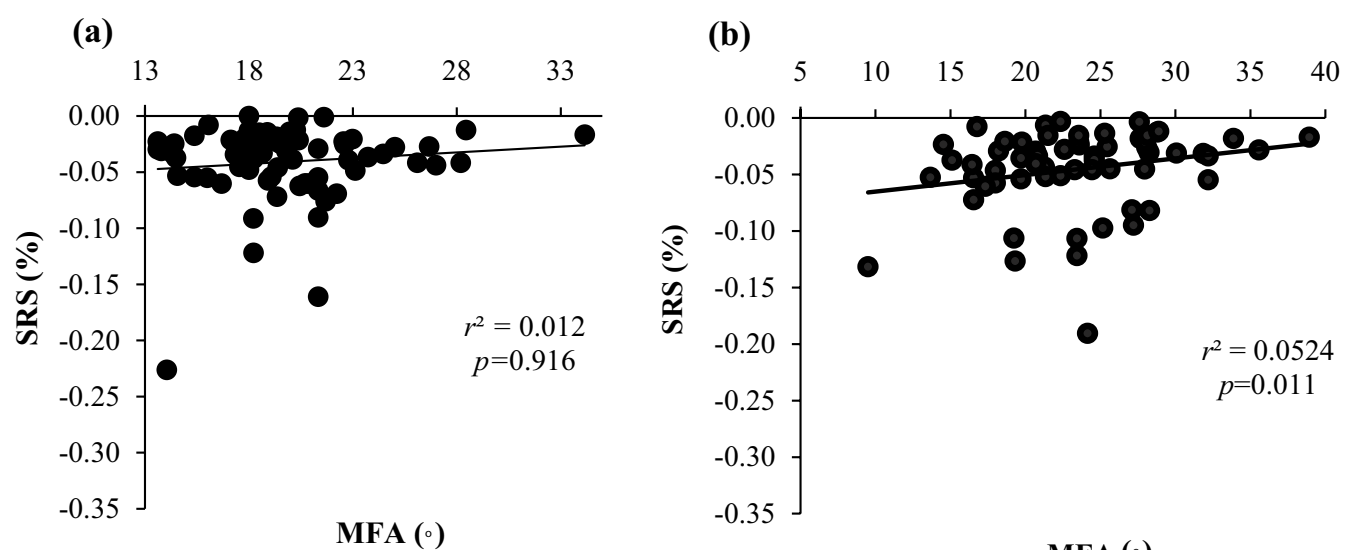

MFA ( $\left.{ }^{\circ}\right)$

Fig. 9 The relationship between MFA and SRS at each measurement point in each tested tree in two trial sites a Butuan trial site and $\mathbf{b}$ Cagayan de Oro trial site 


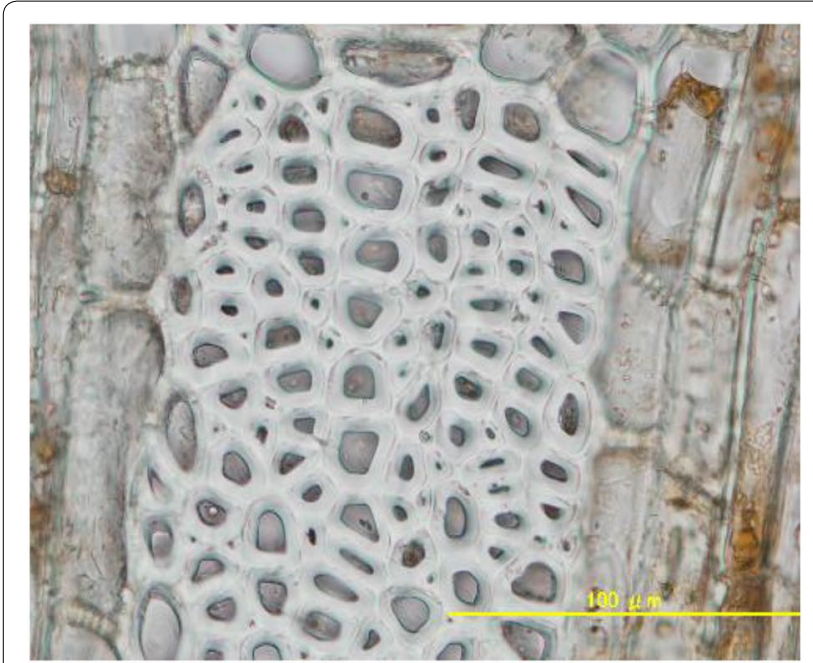

(a) Normal Wood $(\mathrm{SRS}=\mathbf{- 0 . 0 4 \%})$

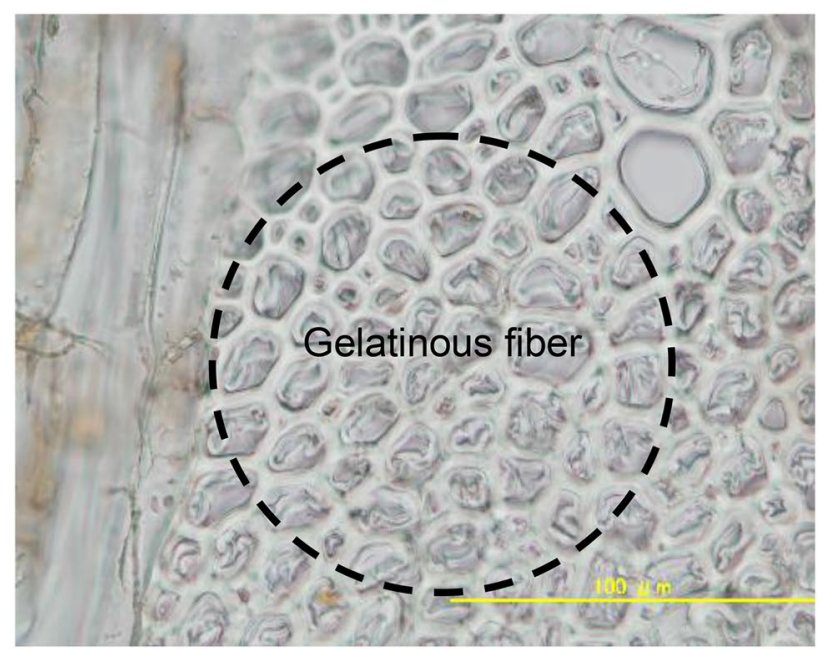

(b) Tension Wood (SRS $=-\mathbf{0 . 3 3} \%)$

Fig. 11 Microscopic image of a transverse section of a normal wood and $\mathbf{b}$ tension wood (tree with inclined stem in Butuan trial site) of an 8-year-old BL mahogany. Tension wood G-fiber contains a thick G-layer (circled). Scale $100 \mu \mathrm{m}$

\section{Abbreviations}

BL: Big leaf; SRS: longitudinal released strain of surface growth stresses; $\mathrm{DBH}$ : diameter at breast height; XD: xylem density; FL: fiber length; FW: fiber width VL: vessel element length; VW: vessel element width; MFA: microfibril angle; MOE: modulus of elasticity; MOR: modulus of rupture; G-fiber: gelatinous-fiber; G-layer: gelatinous layer.

\section{Acknowledgements}

Support from Department of Environment and Natural Resources-Ecosystems Research and Development Bureau (DENR-ERDB) and Forest and Wetland Research, Development and Extension Center (ERDB-FWRDEC) is also gratefully acknowledged. We also acknowledge the contribution of Dr. Editha C. Cedicol, Director of Nagoya University Asian Satellite Campus-Philippines in manuscript editing.

\section{Authors' contributions}

All the authors have contributed to the manuscript and take all responsibilities for the entire content of the manuscript. All authors read and approved the final manuscript.

\section{Funding}

This study was supported by the Nagoya University Asia Satellite Campus Institute under the Transnational Doctoral Programs for Leading Professional in Asian Countries, the Japan International Cooperation Agency (JICA) and Southeast Asian Regional Center for Graduate Study and Research in Agriculture (SEARCA).

\section{Availability of data and materials}

Not applicable.

\section{Competing interests}

The authors declare that they have no competing interests.

\section{Author details}

'Laboratory of Wood Physics, Graduate School of Bio-agricultural Sciences, Nagoya University, Furo-Cho, Chikusa, Nagoya 464-8601, Japan. ${ }^{2}$ Forest and Wetland Research, Development and Extension Center, Ecosystem Research and Development Bureau of Department of Environment and Natural Resources, Bislig, Philippines. ${ }^{3}$ College of Forestry and Natural Resources, University of the Philippines, Los Baños, Laguna, Philippines.
Received: 12 March 2019 Accepted: 8 July 2019

Published online: 24 July 2019

\section{References}

1. Mead D, Odoom F (2001) Promotion of valuable hardwood plantations in the tropics. A global overview. FAO, Rome

2. Lugo AE, Figueroa JC, Alayon M (2003) Big-leaf mahogany genetics, ecology and management. Springer, New York

3. Hammond D (2002) Hardwood Programme in Fiji, Solomon Island, and Papua New Guinea. Forest Plantations Working Paper 21. FAO, Rome

4. ITTO (2014) Biennial review and assessment of the world timber situation 2013-2014 (Appendix 3). Int Trop Timber Assoc, Tokyo, pp 160-161

5. Grogan J, Blundell AG, Landis RM, Youatt A, Gullison RE, Martinez M, Kómetter R, Lentini M, Rice RE (2010) Over-harvesting driven by consumer demand leads to population decline: big-leaf mahogany in South America. Conserv Lett 3:12-20

6. Krisnawati H, Kallio M, Kanninen M (2011) Swietenia macrophylla King: ecology, silviculture and productivity. CIFOR, Bogor

7. Langbour P, Gerard J, Roda JM, Fauzi PA, Guibal D (2011) Comparison of wood properties of planted big-leaf mahogany (Swietenia macrophylla) in Martinique island with naturally grown mahogany from Brazil, Mexico and Peru. J Trop For Sci 23:252-259

8. Ponce SS (1933) Mahogany as a reforestation crop. Makiling Echo 12:7-7

9. Abarquez A, Bush D, Ata J, TolentinoJr EL, Gilbero D (2015) Early growth and genetic variation of mahogany (Swietenia macrophylla) in progeny test planted in Northern Mindanao, Philippines. J Trop For Sci 27:314-324

10. Kubler H (1987) Growth stresses in trees and related wood properties. For Abstr 48:131-189

11. Gril J, Jullien D, Bardet S, Yamamoto H (2017) Tree growth stress and related problems. J Wood Sci 63:411-432

12. Boyd JD (1977) Relationship between fiber morphology and shrinkage of wood. Wood Sci Technol 11:3-22

13. Okuyama T, Yamamoto H, Iguchi M, Yoshida M (1990) Generation process of growth stresses in cell walls. II. Growth stresses in tension wood. Mokuzai Gakkaishi 36:797-803

14. Washusen R, Llic J, Waugh G (2003) The relationship between longitudinal growth strain and the occurrence of gelatinous fibers in 10- and 11-year-old Eucalyptus globulus Labill. Holz Roh Werkst 61:299-303 
15. Kojima M, Yamamoto H, Okumura K, Ojio Y, Yoshida M, Okuyama T, Ona T, Matsune K, Nakamura K, Ide Y, Marsoem SN, Sahri MH, Hadi YS (2009) Effect of the lateral growth rate on wood properties in fast-growing hardwood species. J Wood Sci 55:417-424

16. Kojima M, Yamamoto H, Saegusa K, Minoru YF, Yoshida M, Yamashita S, Nakai T (2012) Anatomical and chemical factors affecting tensile growth stress in Eucalyptus grandis plantations at different latitudes in Brazil. Can J For Res 42:134-140

17. Arganbright DG, Bensend DW, Manwiller FG (1970) Influence of gelatinous fibers on the shrinkage of silver maple. Wood Sci 3:83-89

18. Wardrop AB, Dadswell HE (1955) The nature of reaction wood. IV Variations in cell wall organization of tension wood fibers. Austral J Bot 3:177-189

19. Jourez B, Riboux A, Leclercq A (2001) Anatomical characteristics of tension wood and opposite wood in young inclined stems of poplar (Populus euramericana cv. Ghoy). IAWA J 22:133-157

20. Onaka F (1949) Studies on compression and tension wood. Wood Res Bull Wood Res Inst Kyoto Univ 24:1-88

21. Panshin AJ, Zeeuw CDE (1980) Textbook of wood technology: structure, identification, properties, and uses of the commercial woods of the United States and Canada, 2nd edn. McGraw-Hill, New York

22. Parham RA, Robinson KW, Isebrands JG (1977) Effects of tension wood on Kraft paper from a short-rotation hardwood (Populus tristis No. 1). Wood Sci Technol 11:291-303

23. Philippine Atmospheric, Geophysical and Astronomical Services Administration (2018) Climatological-normal. http://bagong.pagasa.dost.gov.ph/ index.php/climate/climatological-normals. Accessed 12 May 2019

24. Kojima M, Yamamoto H, Marsoem SN, Okuyama T, Yoshida M, Nakai T, Yamashita S, Saegusa K, Matsune K, Nakamura K, Inoue Y, Arizono T (2009) Effects of the lateral growth rate on wood quality of Gmelina arborea from 3.5-, 7- and 12-year-old plantations. Ann For Sci 66:1-6

25. Okuyama T, Sasaki Y, Kikata Y, Kawai N (1981) The seasonal change in growth stress in the tree trunk. Mokuzai Gakkaishi 27:350-355

26. Yamamoto H, Okuyama T, Iguchi M (1989) Measurement of surface growth stress in a leaning stem. Mokuzai Gakkaishi 35:595-601

27. Yoshida M, Okuyama T (2002) Technique for measuring growth stress on the xylem surface using strain and dial gauges. Holzforschung 56:461-467

28. Kollmann FFP, Cote WA Jr (1968) Principles of wood science and technology. I. Solid wood. Springer, Berlin

29. Saiki H, Xu Y, Fujita M (1989) The fibrillar orientation and microscopic measurement of the fibril angles in young tracheid walls of Sugi (Cryptomeria japonica). Mokuzai Gakkaishi 35:786-792

30. Cheng Z, Fujiwara S, Ohtani Y, Sameshima K (2000) A new method of sample preparation for kenaf bast fiber length analysis with automated fiber length analyzer. Holzforschung 54:213-218

31. Cave ID (1966) Theory of X-ray measurement of microfibril angle. For Prod J 16(10):37-42
32. Meylan BA (1967) Measurement of microfibril angle by X-ray diffraction. For Prod J 17:51-58

33. Yamamoto H, Okuyama T, Yoshida M (1993) Method of determining the mean microfibril angle of wood over wide range by the improved Cave's method. Mokuzai Gakkaishi 39:375-381

34. Wahyudi I, Okuyama T, Hadi YS, Yamamoto H, Watanabe H, Yoshida M (2001) Relationships between released strain and growth rate in 39-yearold Tectona grandis planted in Indonesia. Holzforschung 55:63-66

35. Chafe SC (1995) Peripheral growth stress and tree diameter in Eucalyptus. J Inst Wood Sci 13:523-525

36. Zobel BJ, Jett JB (1995) Genetics of wood production. Springer, New York

37. Kojima M, Yamamoto H, Yoshida M, Ojio Y, Okumura K (2009) Maturation property of fast-growing hardwood plantation species: a view of fiber length. For Ecol Manag 257:15-22

38. Chow KY (1946) A comparative study of the structure and composition of tension wood in beech (Fagus sylvatica L.). Forestry 20:62-77

39. Ruelle J, Clair B, Beauchêne J, Prevost MF, Fournier M (2006) Tension wood and opposite wood in 21 tropical rain forest species. 2. Comparison of some anatomical and ultrastructural criteria. IAWA J 27:329-338

40. Barnett JR, Bonham VA (2004) Cellulose microfibril angle in the cell wall of wood fibres. Biol Rev 79:461-472

41. Baba K, Ona T, Takabe K, Itoh T, Ito K (1996) Chemical and anatomical characterization of the tension wood of Eucalyptus camaldulensis $\mathrm{L}$. Mokuzai Gakkaishi 42:795-798

42. Okuyama T, Yamamoto H, Yoshida M, Hattori Y, Archer RR (1994) Growth stresses in tension wood: role of microfibrils and lignification. Ann Sci For 51:291-300

43. Yamamoto H, Okuyama T, Sugiyama K, Yoshida M (1992) Generation process of growth stresses in cell walls. IV. Action of the cellulose microfibril upon the generation of the tensile stresses. Mokuzai Gakkaishi 38:107-113

44. Yoshida M, Okuda T, Okuyama T (2000) Tension wood and growth stress induced by artificial inclination in Liriodendron tulipifera Linn. and Prunus spachiana Kitamura f. ascendens Kitamura. Ann For Sci 57:739-746

45. Yamamoto H, Abe K, Arakawa Y, Okuyama T, Gril J (2005) Role of gelatinous layer (G-layer) on the origin of the physical properties of the tension wood of Acer sieboldianum. J Wood Sci. 51:222-233

46. Wardrop AB, Dadswell HE (1955) The nature of reaction wood IV: variations in cell wall organization of tension wood fibers. Aust J Bot 3:177-189

\section{Publisher's Note}

Springer Nature remains neutral with regard to jurisdictional claims in published maps and institutional affiliations.

\section{Submit your manuscript to a SpringerOpen ${ }^{\odot}$ journal and benefit from:}

- Convenient online submission

- Rigorous peer review

- Open access: articles freely available online

- High visibility within the field

- Retaining the copyright to your article

Submit your next manuscript at springeropen.com 